Paulina Pieprzyk*

\title{
Ewolucja zadań JST w systemie ochrony zdrowia
}

Samorząd terytorialny niemalże od początków swojego istnienia brał czynny udział $\mathrm{w}$ realizowaniu zadań z zakresu zdrowia publicznego. $\mathrm{Z}$ czasem zmieniał się zakres odpowiedzialności samorządu, rodzaj i liczba nakładanych na niego zadań, jednakże niezmienny pozostał stały udział jednostek samorządu terytorialnego (dalej: JST) w systemie ochrony zdrowia. Artykuł ma pokazać, jak z biegiem lat, rozpoczynając aż od czasu zaborów i kończąc na latach współczesnych, zmieniała się rola jednostek samorządu terytorialnego w systemie ochrony zdrowia, jakie miało to konsekwencje dla stanu finansów samorządowych i na ile wprowadzane rozwiązania odpowiadały podstawowym wartościom prawidłowej legislacji.

Kwestia zdrowia publicznego, pierwotnie podporządkowana Kościołowi, $\mathrm{z}$ czasem stała się sprawą o wymiarze publicznym. W miarę organizowania się życia miejskiego (już od czasów późnego średniowiecza) odpowiedzialne za zapewnienie opieki chorym stały się miasta ${ }^{1}$. Na różne sposoby starano się zagwarantować obywatelom podstawową opiekę medyczną, np. na wniosek H. Kołłątaja został uchwalony dekret nakazujący miastom i miasteczkom wysyłanie do Szkoły Głównej Koronnej i Wileńskiej kandydatów na studia medyczne oraz finansowanie tej nauki². Po ukończeniu nauki ,,patentowani lekarze mieli pracować w swoich miastach, które łożyły na ich kształcenie"s.

W zaborze austriackim publiczna służba zdrowia była podporządkowana władzom administracyjnym. Zajmowały się one głównie sprawami, które dzisiaj leżą w gestii stacji sanitarno-epidemiologicznych. Leczenie było sprawą prywatną, ale część ludności korzystała z lecznictwa ubezpieczeniowego, które zostało zorganizowane pod koniec XIX w. Miejscowy samorząd miał natomiast dostarczać pełnej pomocy najuboższej części ludności. W zaborze austriackim działała policja zdrowia (policja lekarska), która pełniła funkcje koordynujące i nadzorujące,

* Mgr Paulina Pieprzyk - Katedra Prawa Finansowego, Wydział Prawa i Administracji, Uniwersytet im. Adama Mickiewicza w Poznaniu.

1 Z. Gajda, Do historii medycyny wprowadzenie, Kraków 2011, s. 190.

2 B. Seyda, Dzieje medycyny w zarysie, Warszawa 1977, s. 472.

3 Ibidem. 
a sam samorząd terytorialny (i jego instytucje) zajmował się wykonawstwem. Zwierzchnim organem publicznej służby zdrowia była Najwyższa Rada Zdrowia, nad którą pieczę sprawowało Ministerstwo Spraw Wewnętrznych. Nadzór nad szpitalami, szpitalami dla psychicznie chorych, szpitalami położniczymi, zakładami dla podrzutków sprawował Naczelnik Kraju. Natomiast rolę wykonawców zaleceń publicznej służby zdrowia pełnili lekarze urzędnicy państwowej i samorządowej służby zdrowia - lekarze urzędujący jako pracownicy Najwyższej Rady Zdrowia, lekarze powiatowi, okręgowi, gminni i miejscy. W 1888 r. w Galicji wprowadzono obowiązkowe ubezpieczenia robotników na wypadek zachorowania oraz kasy chorych do wykonania tego ubezpieczenia ${ }^{4}$.

W zaborze pruskim sprawami zdrowia publicznego zajmowały się zarządy prowincjonalne i podległe im samorządy powiatowe, gminne i miejskie. Za politykę zdrowotną (w tym również policję sanitarną) był odpowiedzialny Wydział Lekarski w Ministerstwie Spraw Duchowych, Edukacyjnych i Lekarskich. Wydział Lekarski odpowiadał za funkcje nadzorcze w zakresie wykonywania praktyki lekarskiej, sprzedaży leków, a także działalności szpitali i publicznych oraz prywatnych zakładów leczniczych. Na poziomie prowincji organem doradczym zajmującym się zdrowiem publicznym były kolegia lekarskie, zaś powiatowym zdrowiem publicznym zajmował się podporządkowany urzędowi powiatowemu fizyk. W $1883 \mathrm{r}$. w państwie pruskim wprowadzono obowiązkowe ubezpieczenia społeczne na wypadek zachorowania oraz kasy chorych ${ }^{5}$.

Natomiast w przypadku zaboru rosyjskiego przyjęty model różnił się od dwóch poprzednich - charakteryzowała go silna centralizacja. Zarządzanie służbą zdrowia było scentralizowane, podporządkowane i uzależnione od administracji. Aż do wybuchu I wojny światowej na terenie Królestwa Polskiego działała tzw. policja lekarska (medycyna policyjna). Z końcem XIX w. służba lekarska została podporządkowana departamentowi lekarskiemu w Ministerstwie Spraw Wewnętrznych w Petersburgu. Rada Lekarska i Wydział do Spraw Lekarskich w Komisji Spraw Wewnętrznych oraz Urząd Głównego Inspektora Służby Zdrowia zostały zlikwidowane. Głównym urzędem zajmującym się administrowaniem służbą zdrowia był Urząd Lekarski (podporządkowany policji, która zajmowała się nadzorem sanitarnym). Magistrat miasta Warszawy musiał zatem zwracać się do Urzędu Lekarskiego za pośrednictwem policji. Służba zdrowia na szczeblu guberni, powiatu i gminy była podporządkowana urzędom administracji państwowej ${ }^{6}$.

Po odzyskaniu niepodległości podjęto próbę skonsolidowania tych trzech odmiennych systemów. „Sprawy zdrowotne” uregulowano w zasadniczej ustawie sanitarnej z dnia 19 lipca 1919 r. (Dz. U. z 1919 r. Nr 63, poz. 371). Nadzór zwierzchni nad „wszystkiemi sprawami zdrowotnemi w państwie oraz zwierzch-

\footnotetext{
${ }^{4}$ E. Więckowska, Lekarze jako grupa zawodowa w II Rzeczypospolitej, Wrocław 2004, s. 13.

5 Ibidem, s. 18.

${ }^{6}$ Ibidem, s. 25.
} 
nie kierownictwo spraw lekarskich" zostało przekazane ministrowi zdrowia publicznego. Natomiast ciała samorządowe zobowiązane zostały do „pieczy nad zdrowiem ludności i bezpośredniego wykonawstwa" - pod nadzorem i opieką władz państwowych (art. 1). Kognicji ministra zdrowia publicznego zostały poddane m.in.: zwalczanie chorób (głównie zakaźnych), szpitalnictwo, pielęgniarstwo, ratownictwo, zakłady lecznicze (publiczne i prywatne), sanitarno-lekarska opieka nad dzieckiem i nad macierzyństwem, zaopatrzenie w wodę, nadzór sanitarny nad środkami żywności, inspekcja sanitarna mieszkań, współdziałanie w zwalczaniu alkoholizmu, a nawet „współdziałanie w sprawach związanych ze zjawiskami emigracji ludności” (art. 2 pkt 2). Samorządy zobowiązane zostały m.in. do pieczy nad: czystością powietrza, gleby i wody, zaopatrzeniem ludności w wodę pitną, przestrzeganiem przepisów sanitarnych obowiązujących przy budowie i przebudowie domów, osobistą czystością mieszkańców, zapewnieniem chorym należytej opieki lekarskiej i pomocy fachowej dla położnic. Miały również współdziałać z władzami rządowymi przy zwalczaniu chorób zakaźnych i ich zapobieganiu, w sprawach nadzoru nad produktami spożywczymi (art. 3). Zarządy komunalne zobowiązane zostały m.in. do zakładania i utrzymywania szpitali, przychodni, przytułków, utrzymywania lekarzy sanitarnych, pielęgniarek i akuszerek gminnych oraz urządzeń sanitarno-technicznych (art. 4). Ustawodawca przewidział również, że wydatki wynikające z nałożonych na samorządy obowiązków w art. 3 w całości obciążają związki komunalne. Jednakże, w razie uchylania się gmin od ,asygnowania niezbędnych sum, odpowiednie sumy mogą być wprowadzone do budżetu gminy przez władze nadzorcze na wniosek ministra zdrowia publicznego" (art. 7). Wydatki związane ze współdziałaniem samorządów z władzami rządowymi w sprawach związanych ze zwalczaniem i zapobieganiem chorób zakaźnych oraz w zwalczaniu nierządu i chorób wenerycznych miały być ponoszone przy wsparciu Skarbu Państwa (jednakże wbrew zapowiedzi ustawodawcy nie zostały wydane żadne akty normatywne precyzujące ten obowiązek). Ustawodawca przewidział, że w sytuacjach wyjątkowych gminy, które wykażą, że ich stan finansowy „nie pozwala na całkowite przeprowadzenie zarządzeń sanitarnych i technicznych" mogą otrzymać odpowiednią pomoc ze Skarbu Państwa za pośrednictwem Ministerstwa Zdrowia Publicznego (art. 9).

Jednostki samorządu terytorialnego zostały zobowiązanie do zorganizowania i sfinansowania własnej opieki medycznej (włączając w to szpitalnictwo). Udział finansów państwa przeznaczanych na opiekę zdrowotną określa się jako $16 \%$ wydatków na zdrowie ogółem. Pozostałe $84 \%$ pochodziło głównie z budżetów jednostek samorządów terytorialnych, dalej fundacji społecznych, darowizn. Biedne gminy wiejskie stać było głównie na pokrywanie kosztów leczenia szpitalnego i usług świadczonych przez położne. Codzienna opieka medyczna była zapewniana głównie przez samorządy i ubezpieczalnie, rola państwa ograniczała się głównie do działań legislacyjnych i sprawowania nadzoru nad działalnością samorządów. Organizacja opieki nad chorymi opierała się głównie na: 
- pomocy zorganizowanej przez samorządy (przychodnie, ośrodki zdrowia, lekarze gminni, okręgowi, przychodnie szpitalne);

- ubezpieczeniach na wypadek choroby i macierzyństwa;

- sieci ośrodków;

- państwowej organizacji pomocy dla pracowników państwowych;

- samorządowej organizacji pomocy dla pracowników samorządowych;

- organizacji pomocy dla pracowników przedsiębiorstw państwowych;

- organizacji pomocy dla pracowników banków państwowych;

- organizacji pomocy dla słuchaczy wyższych uczelni;

- organizacji pomocy dla robotników rolnych.

Warto ponownie podkreślić różnice występujące pomiędzy samorządami miejskimi a wiejskimi - aż 6 z 9 wymienionych wyżej instytucji było dostępnych wyłącznie dla mieszkańców miast. Tylko organizacja samorządowa, robotników rolnych i sieć ośrodków mogły świadczyć pomoc medyczną mieszkańcom wsi. Organizacja lecznicza dwudziestolecia międzywojennego charakteryzowała się dużym rozwarstwieniem.

Dla porządku należy krótko wspomnieć o przyjętych rozwiązaniach w PRL. Po II wojnie światowej to państwo przejęło obowiązek zapewnienia opieki medycznej ludności. Przyjęty centralistyczny model finansowania, zwany modelem Siemaszki, opierał się na koncepcji narodowej służby zdrowia finansowanej z budżetu państwa i niemal powszechnym dostępie do świadczeń medycznych (gwarantowała to zresztą konstytucja lipcowa z 1952 r.) ${ }^{7}$. Zakłady opieki zdrowotnej były finansowane z budżetu państwa.

Proces reformowania systemu ochrony zdrowia rozpoczął się na przełomie lat 80. i 90. XX w. Kraje Europy Środkowo-W schodniej, w tym Polska, podlegały najsilniejszym procesom transformacji. Aż do początku lat 90. XX w. obowiązywał w nich scentralizowany system organizacji oraz dostarczania świadczeń zdrowotnych. Transformacja systemu przyniosła m.in. zmianę sposobu finansowania z planowania budżetowego na rzecz obowiązkowych ubezpieczeń zdrowotnych finansowanych ze składek pracowników i pracodawców, wzrost autonomii sektora zdrowotnego tak na szczeblu terytorialnym, jak i w placówkach ochrony zdrowia w sektorze publicznym ${ }^{8}$. W większości krajów przechodzących proces transformacji zmodyfikowano już system ochrony zdrowia - głównie ,zmiany te polegały na utworzeniu funduszu ubezpieczeń zdrowotnych oraz próbie wprowadzenia dobrowolnych ubezpieczeń społecznych"9. W Polsce obecnie głównym źródłem finansowania systemu ochrony zdrowia są obowiązkowe składki ubezpieczeniowe w wysokości 9\% dochodów osobistych, z czego 7,75\% odliczane jest od podatku dochodowego, a 1,25\% pokrywa ubezpieczony.

${ }^{7}$ Art. 60 pkt 1 Konstytucji Polskiej Rzeczypospolitej Ludowej, Dz. U. z 1952 r. Nr 33, poz. 232.

${ }^{8}$ A. Depta, Transformacja wspótczesnych systemów zdrowotnych w wybranych krajach, [w:] J. Suchecka (red.), Finansowanie ochrony zdrowia, wybrane zagadnienia, Warszawa 2011, s. 47.

${ }^{9}$ Ibidem. 
Wraz z reaktywacją samorządu terytorialnego jego rola w systemie ochrony zdrowia znacząco wzrosła. Samorząd terytorialny został zobowiązany do przejęcia zadań z zakresu ochrony zdrowia jako zadań własnych. Początkowo obowiązek ten dotyczył tylko gmin. Zgodnie z art. 7 ust. 1 pkt 5 ustawy z dnia 8 marca 1990 r. o samorządzie gminnym (Dz. U. z 1996 r. Nr 13, poz. 74) jako zadanie własne gminy zostały wskazane sprawy ochrony zdrowia. Jednakże art. 8 ust. 1 tzw. ustawy kompetencyjnej z dnia 17 maja 1990 r. (ustawa o podziale zadań i kompetencji określonych w ustawach szczególnych pomiędzy organy gminy a organy administracji rządowej oraz o zmianie niektórych ustaw - Dz. U. Nr 34, poz. 198 ze zm.) określał prowadzenie zakładów społecznych służby zdrowia, dotychczas podporządkowanych radom narodowym i terenowym organom administracji państwowej stopnia podstawowego, jako zadanie zlecone. Prowadzenie zakładów opieki zdrowotnej podporządkowanych wojewodzie mogło zostać powierzone gminie na podstawie porozumienia ${ }^{10}$. Początkowo samorządy zaczęly przejmować jednostki podstawowej opieki zdrowotnej właśnie na podstawie indywidualnych porozumień z organami administracji rządowej (czyli jako zadania zlecone). W 1995 r. na podstawie miejskiego programu pilotażowego i art. 3 tzw. ustawy miejskiej z 1995 r. gminom o statusie miast zostały przekazane zadania i kompetencje wynikające z ustawy o zakładach opieki zdrowotnej, wcześniej realizowane przez organy rządowej administracji ogólnej - od tego czasu prowadzenie zakładów opieki zdrowotnej stało się zadaniem własnym tych gmin ${ }^{11}$. Finansowanie tych zadań określał art. 11 ww. ustawy, który przewidywał, że dochody własne gmin przejmujących kompetencje i zadania jako zadania własne zwiększa się o kwotę równą iloczynowi wskaźnika udziału w podatku dochodowym od osób fizycznych oraz ogólnej kwoty wpływów w kraju z podatku dochodowego od osób fizycznych zaplanowanych w ustawie budżetowej. Dodatkowo, przewidziano zwiększenie tej kwoty o dodatkowe $2 \%$ z przeznaczeniem na finansowanie nakładów inwestycyjnych. W ten sposób jednostki opieki zdrowotnej, nad którymi dotychczasową pieczę sprawowali wojewodowie, na podstawie ich decyzji stały się komunalnymi jednostkami organizacyjnymi ${ }^{12}$, a uprawnienia organu założycielskiego przeszły z wojewodów na rzecz JST ${ }^{13}$. Zatem odpowiedzialnymi za sprawowanie funkcji założycielskich i nadzorczych nad zakładami

10 Wyrok Naczelnego Sądu Administracyjnego z dnia 15 listopada 1995 r., I SA 1394/94.

${ }^{11}$ Rozporządzenie Rady Ministrów z 13 lipca 1993 r. w sprawie określenia zadań i kompetencji z zakresu rządowej administracji ogólnej i specjalnej, które mogą być przekazane niektórym gminom o statusie miasta, wraz z mieniem służącym do ich wykonywania, a także zasad i trybu przekazania (Dz. U. z 1993 r. Nr 65, poz. 309 ze zm.) oraz ustawa z 24 listopada 1995 r. o zmianie zakresu działania niektórych miast oraz o miejskich strefach usług publicznych (Dz. U. z 1997 r. Nr 36, poz. 224 ze zm.).

${ }_{12}$ P. Białynicki-Birula, Zmiany w systemie finansowania ochrony zdrowia w Polsce. Perspektywa międzynarodowa, Kraków 2006, s. 87.

13 J. Niżnik, $W$ poszukiwaniu racjonalnego systemu finansowania ochrony zdrowia, Bydgoszcz 2004, s. 162. 
opieki zdrowotnej stały się samorządy powiatowe i wojewódzkie. Agnieszka Zemke-Górecka pisze, że paradoksalnie samorządy ,nie zakładały [ZOZ-ów - przyp. P. P.], a stały się podmiotem, który utworzyły"14.

Współcześnie, obowiązek podejmowania działań przez samorząd terytorialny w obszarze ochrony zdrowia wynika wprost z przepisów tzw. ustaw ustrojowych, dotyczących administracji samorządowej. Omawiany wyżej art. 7 ust. 1 pkt 5 ustawy z dnia 8 marca 1990 r. o samorządzie gminnym (Dz. U. z 1996 r. $\mathrm{Nr}$ 13, poz. 74) nakłada na gminę obowiązek zaspokajania potrzeb wspólnoty w zakresie zdrowia; art. 4 ust. 1 pkt 2 ustawy z dnia 5 czerwca 1998 r. o samorządzie powiatowym i art. 14 ust. 1 pkt 2 ustawy z dnia 5 czerwca o samorządzie województwa (Dz. U. z 1998 r. Nr 91, poz. 578, 576) wskazują odpowiednio samorząd powiatowy i samorząd wojewódzki jako właściwe do wykonania określonych ustawami zadań publicznych o charakterze ponadgminnym i wojewódzkim w zakresie promocji i ochrony zdrowia.

Poczynając od początku lat 90 ., równolegle tworzone były zarówno publiczne, jak i niepubliczne zakłady opieki zdrowotnej. Ustawa o zakładach opieki zdrowotnej stwarzała zatem teoretyczną możliwość zróżnicowania stosunków właścicielskich przez tworzenie i przejmowanie zakładów opieki zdrowotnej przez szeroki katalog podmiotów, w tym szczególnie przez gminy ${ }^{15}$. W aktualnym stanie prawnym, uregulowanym ustawą z dnia 15 kwietnia 2011 r. o działalności leczniczej (Dz. U. z 2011 r. Nr 112, poz. 654), podmiot leczniczy może być utworzony i prowadzony w formie spółki kapitałowej albo jednostki budżetowej bądź to przez Skarb Państwa (reprezentowany przez ministra, centralny organ administracji rządowej albo wojewodę), bądź przez JST. Podmioty te mogą przystąpić do spółki kapitałowej wykonującej działalność leczniczą (art. 6 ust. 8), mogą również prowadzić SPZOZ-y. W przypadku samorządowych spółek kapitałowych ustawodawca wyłączył stosowanie przepisów ustawy z 20 grudnia $1996 \mathrm{r}$. o gospodarce komunalnej ${ }^{16}$ oraz wszystkich innych przepisów dotyczących gospodarki komunalnej w ogóle (art. 6 ust. 4).

Z uprawnień właścicielskich JST w stosunku do podmiotów leczniczych wynikają doniosłe konsekwencje finansowe. Zgodnie z art. 59 ust. 2 ww. ustawy jednostka samorządu terytorialnego, jako podmiot tworzący SPZOZ, może (w terminie 3 miesięcy od upływu terminu zatwierdzenia sprawozdania finansowego SPZOZ-u) pokryć ujemny wynik finansowy za rok obrotowy tego zakładu, jeżeli wynik ten po dodaniu kosztów amortyzacji ma wartość ujemną - do wysokości tej wartości (art. 59 ust. 2). W przypadku nieskorzystania z tej możliwości podmiot tworzący w terminie 12 miesięcy od upływu określonego wyżej terminu

${ }^{14}$ A. Zemke-Górecka, Status prawny samodzielnego publicznego zakładu opieki zdrowotnej i jego prywatyzacja, Warszawa 2010, s. 7.

15 Ibidem.

${ }^{16}$ Ustawa z 20 grudnia 1996 r. o gospodarce komunalnej, Dz. U. z 2011 r. Nr 45, poz. 236 (dalej: u.g.n.). 
wydaje rozporządzenie, zarządzenie albo podejmuje uchwałę o zmianie formy organizacyjno-prawnej (czyli o przekształceniu w spółkę kapitałową bądź jednostkę budżetową) lub o likwidacji SPZOZ-u (art. 59 ust. 4). Taki stan prawny stanowi poważne zagrożenie dla stabilności finansowej samorządu terytorialnego - powszechnie wiadomo, że wiele zakładów opieki zdrowotnej odnotowuje poziom zadłużenia przekraczający wysokość budżetów podmiotów je tworzących. W doktrynie podkreśla się, że na samorząd terytorialny przerzuca się zadania dotyczące polityki zdrowotnej państwa, co do zasady stanowiące domenę rządu, bez jednoczesnego zapewnienia odpowiednich środków finansowych. To podmiot tworzący będzie musiał pokryć koszty utrzymania SPZOZ-u w zakresie, w jakim nie są one finansowane przez NFZ i Ministerstwo Zdrowia. „W takiej sytuacji ustawodawca, mimo formalnie występujących alternatyw, skazuje takie zadłużone SPZOZ-y na likwidację lub komercjalizację, która de facto skończyć się może pełną prywatyzacją"17.

Przyjęte rozwiązania z całą pewnością nie realizują postulatów wynikających z podstawowych wartości prawa publicznego - jego precyzji rozumianej jako prawidłowości i przyzwoitości legislacji. Na samorząd terytorialny scedowana została odpowiedzialność za zadania, których realizacja znacznie przekracza faktyczne możliwości jednostek samorządu terytorialnego.

Konieczne wydaje się ujęcie analizowanej problematyki w aspekcie ustrojowym. Prawo do ochrony zdrowia jest prawem podstawowym wynikającym z przyrodzonej i niezbywalnej godności człowieka, którego przestrzeganie władza państwowa jest zobowiązana ochraniać (wyrok TK z dnia 18 grudnia 2002 r., K 43/01). Zasadnicze reguły konstytucyjne, odnoszące się do publicznej służby zdrowia, są zawarte w art. 68 Konstytucji. Przepis ten nakłada na władze publiczne obowiązek zapewnienia obywatelom dostępu do świadczeń opieki zdrowotnej ze środków publicznych (wyrok TK z dnia 18 grudnia 2002 r., K 43/01) ${ }^{18}$. Obowiązek ten obejmuje m.in. ustalenie struktury organizacyjnej publicznej służby zdrowia, z założeniem, iż podstawowym ogniwem realizującym konstytucyjne obowiązki władzy publicznej jest system publicznej służby zdrowia (wyrok TK z dnia 18 grudnia 2002 r., K 43/01).

Cechami współczesnych państw demokratycznych są równość i sprawiedliwość, które uznawane są za zasady konstytucyjne. Artykuł 68 Konstytucji przyznaje każdemu prawo do ochrony zdrowia, w ust. 2 przyznaje się obywatelom, niezależnie od ich sytuacji materialnej, równy dostęp do świadczeń opieki zdrowotnej finansowanej ze środków publicznych. W tym miejscu należy przywołać myśl W. Łączkowskiego, który twierdzi, że ustrojodawca zbyt pochopnie

${ }_{17}$ M. Dercz, T. Rek, Ustawa o działalności leczniczej. Komentarz, System Informacji Prawnej LEX.

${ }_{18}$ Warto podkreślić, iż jednostka samorządu terytorialnego jest także bezpośrednim adresatem art. 68 ust. 2 Konstytucji RP - por. wyrok TK z dnia 12 października 2004 r., sygn. akt K 31/02, OTK-A 2004/9/91. 
deklaruje, że wszyscy obywatele są równi w prawach lub wobec prawa i mają prawo do równego traktowania przez władze publiczne - „równość bezwarunkowo i obiektywnie może obowiązywać tylko w sferze aksjologicznej, w odniesieniu do godności człowieka i praw mających charakter prawa naturalnego. [...] Natomiast w sferze prawa stanowionego równość jest ułomna, stanowi jedynie pochodną decyzji prawodawcy grupującego adresatów norm według cech przez niego wskazanych. Dlatego różne grupy podmiotów mają różne prawa i są różnie traktowane przez prawo. Inne rozwiązania są niemożliwe, a próby siłowej realizacji równości wszystkich obywateli mogłyby prowadzić do regulacji niesprawiedliwych, a nawet szkodliwych ekonomicznie, jak w przypadku finansowania służby zdrowia"19.

Instytucja finansowania służby zdrowia została zbudowana wokół zasady egalitaryzmu, która, zdaniem autora, nie występuje w czystej postaci w żadnym systemie prawnym i w swoich założeniach jest tyle utopijna, co szkodliwa. Władze publiczne są zobowiązane do zapewnienia równego dostępu do świadczeń opieki zdrowotnej niezależnie od sytuacji materialnej obywateli (art. 68 ust. 2 Konstytucji RP). Obowiązek partycypacji w finansowaniu usług medycznych jest zatem powszechny, co oznacza, że spoczywa on również na osobach mniej zamożnych czy wręcz ubogich, które paradoksalnie finansują leczenie osób, których status finansowy jest na tyle wysoki, że same mogą ponosić te koszty. Łączkowski uważa, że „,demoralizujące jest twierdzenie, że odprowadzane przez nich składki zwalniają ich od ponoszenia kosztów”, ponieważ „skłania do ryzykownych zachowań i przerzucania na innych, często mniej zamożnych obywateli obowiązku ponoszenia kosztów leczenia" ${ }^{20}$. Poważną i główną przeszkodą uniemożliwiającą nie tyle kompleksowe, co skuteczne zreformowanie służby zdrowia jest właśnie powołany zapis konstytucyjny. Dotychczas podejmowane próby reform mogą skutkować tylko „drobnymi oszczędnościami”, nie dotykają natomiast źródła problemów, bo „największe emocje wywołuje nie istota problemu, lecz to, w jakiej formie mają być zorganizowane instytucje opieki zdrowotnej i kto ma być ich właścicielem". Autor proponuje, by wprowadzić w życie postulaty zasady pomocniczości, zgodnie z którymi koszty leczenia osób ubogich byłyby pokrywane ze środków publicznych, bez względu na to, kto byłby właścicielem danego szpitala. Pozostała część musiałaby pokryć samodzielnie koszty leczenia ${ }^{21}$.

Podobnie na problem ten zwraca również uwagę Z. Woźniak, pisząc, że konieczna przebudowa sektora usług publicznych w Polsce nie może oznaczać powrotu do rozwiązań mających $\mathrm{w}$ tle stosowanie uproszczonej zasady egali-

19 W. Łączkowski, Prawne zasady równości i sprawiedliwości, „Ruch Prawniczy, Ekonomiczny i Socjologiczny" 2011, nr 2, s. 62.

${ }^{20}$ W. Łączkowski, Finanse publiczne XXI w. - egalitaryzm czy zasada pomocniczości, [w:] A. Dobaczewska, E. Juchniewicz, T. Sowiński (red), System finansów publicznych. Prawo finansowe wobec wyzwań XXI wieku, Warszawa 2010, s. 22.

${ }^{21}$ Ibidem. 
taryzmu, bowiem mniej zamożni obywatele, od których pochodzi większość wpływów podatkowych, wbrew swej woli są zmuszeni pomagać osobom, które samodzielnie mogą finansować własne potrzeby - oznacza to, że pochodzące z zasobów publicznych świadczenia w jednakowym wymiarze trafiają do wszystkich obywateli, niezależnie od ich sytuacji materialnej, co powoduje ciągle rosnące wydatki. Warto podkreślić, że „egalitarny uniwersalizm generuje spiralę takich niekorzystnych zjawisk, jak wysokie stale rosnące obciążenia daninami publicznymi (podatki, opłaty, obowiązkowe składki), które ściągane w nadmiarze opóźniają rozwój gospodarczy i zwiększają zapotrzebowanie na pomoc społeczną ze strony ubożejących obywateli’’22.

Należy rozważyć, czy system ochrony zdrowia został zbudowany w oparciu o zasadę pomocniczości, zgodnie z którą władze publiczne koncentrują się na tych zadaniach, których nie można przekazać innym podmiotom i które powinny być wypełniane przez sektor publiczny w imię najszerzej rozumianego interesu publicznego, czy też mamy do czynienia z obserwowanym współcześnie wycofywaniem się państwa z wielu jego wcześniejszych zobowiązań. Dotyczy to sektora ochrony zdrowia, ale także - edukacji, polityki kulturalnej czy nawet bezpieczeństwa publicznego. Zjawisko to pogłębia dodatkowo kryzys finansów publicznych, który jest argumentem na rzecz ,jeszcze szybszego niż dotąd przekształcania państwa rozbudowanych zobowiązań (lub chociaż obietnic) socjalno-opiekuńczych w państwo, które co prawda nadal gwarantuje określone świadczenia, lecz na bezpiecznym dla siebie, relatywnie niskim poziomie"23. Obiecując powszechny dostęp do usług publicznych, państwo musi przejąć odpowiedzialność za zorganizowanie odpowiedniego systemu infrastrukturalno-finansowego. Należy pamiętać, że stosunki finansowe między państwem i samorządem terytorialnym w świetle postulatów dotyczących organizacji nowego systemu prawa publicznego miały charakteryzować partnerstwo i współodpowiedzialność - aktualny sposób organizacji systemu ochrony zdrowia i zajmowana w nim pozycja JST stanowią zaprzeczenie tych postulatów ${ }^{24}$. Nadal zatem aktualny pozostaje postulat sformułowany przez Klemensa Łazarowicza w 1936 r.: „Obecny stan rzeczy wymaga gwałtownie reformy. Samorząd powinien posiadać własną organizację służby zdrowia, któraby była w stanie pełnić obowiązki, nałożone na samorządy przez ustawę"25.

${ }^{22}$ Ibidem, s. 154.

23 R. Drozdowski, Władza państwowa a kryzys finansów publicznych, czyli o tym, że nie ma tego złego, co by na dobre nie wyszło, „Ruch Prawniczy, Ekonomiczny i Socjologiczny” 2011, nr 3, s. 127.

${ }^{24}$ T. Dębowska-Romanowska, Prawo finansowe po transformacji ustrojowej, „Ruch Prawniczy, Ekonomiczny i Socjologiczny" 2011, nr 3, s. 84.

25 J. K. Łazarowicz, Zadania samorzadu w dziedzinie zdrowia i opieki spotecznej, „Samorząd Miejski" 1936, nr 14-15, s. 4. 